\title{
COMMEMORATION
}

\section{THE CENTENARY OF PROFESSOR ARPÁD TESÁR}

\author{
Alexander TESÁR ${ }^{1, *}$ \\ ${ }^{1}$ retired professor, Bratislava, Slovakia. \\ corresponding author: alexander.tesar@gmail.com.
}

\begin{abstract}
On 1st February 2019 is celebrated the birthday centenary of great Slovak scientist and engineer - professor Arpád Tesár (1919 - 1989). His name is connected with many bridges, engineering structures and scientific works being appreciated by the technical community worldwide.
\end{abstract}

Arpád Tesár was born in railway family in Vrutky. He graduated on the college in Liptovsky Mikulas and for two years studied the architecture on The Technical University in Brno. In the year 1939, when Czech universities during protectorate time were closed, he obtained the german Humboldt stipendium and continued his study of structural engineering on the famous Charlottenburg Technical University in Berlin. As awarded alumni of the University, he worked there as an assistant of professor Schleicher and in advance as a structural engineer in aircraft company MesserschmidtWerke in Germany.

In the post-war time, he significantly contributed to the establishment of the industrial basis of Czechoslovakia. Industrial structures in Istebne, Krompachy, Brezno and Podbrezova bear the seal of his invention from that time. Interesting bridge structures, such as the prestressed suspension pipeline bridge in Kralupy or suspension conduit bridge in the harbor of Bratislava and others, designed by him, are acknowledged and admired by the technical community until now.

$\mathrm{He}$ acted on the bridge department of Slovak Railways in Bratislava, where he orchestrated such structures as The Red Bridge in Bratislava, the railway part of the Old Bridge crossing the Danube in Bratislava, the viaducts in Tisovec and Banovce as well as a lot of other railways and industrial structures in Czechoslovakia.

He continued as director of Design department of Vitkovice Steel in Bratislava and suggested a number of great steel bridges and engineering structures. In his following function as director of Metallurgical Institute in Bratislava, he designed a number of structures of metallurgical industry in Czechoslovakia.

His scientific and development activities were continued at the Welding Institute in Bratislava. He acted there as head of the Department of Welded Structures and in cooperation with professor Čabelka, they developed new and unique welding technologies for steel bridges.

In advance, he worked on the Slovak Technical University in Bratislava, where as head of the Chair of Steel and Timber Structures and Bridges educated several generations of statics, bridge builders and structural engineers.

The famous panorama of Bratislava is embellished by the magnificent silhouette of The Bridge of Slovak National Uprising, crossing the Danube. It is a courageous structure, design and erection of which was one of the tops of engineering invention of professor Tesar. The bride was awarded as The Structure of Century in Slovakia. Together with the Eiffel Tower in Paris, Burj al Khalifa in Dubai, Shreds in London and other famous structures, the bridge was established as the member of prestigious World Association of Tall Towers, with excellent position there due to its unique skew pylon.

The bridge is considered as one of nicest bridges worldwide. It is fascinating structure admired by technical community and appearing as myth in the books of bridge engineering. 


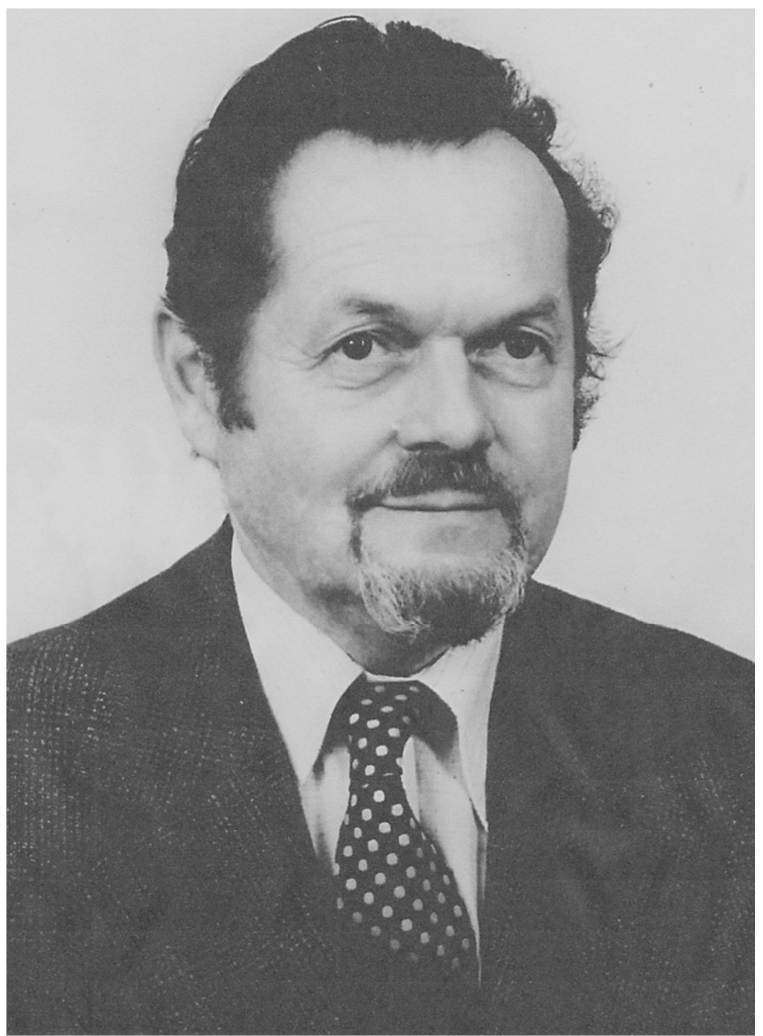

Fig. 1: Professor Arpád Tesár.

The basic idea of design was the creation of the counterbalance between the skew pylon on one side and architectonic solitaires of the Castle and St. Martin's Cathedral on the opposite side of Danube. Such an idea is very impressive until now.

His motto "statically perfect structure is also aesthetically faultless", which is the product of work and thinking of great engineers, is full present in all his designs and structures.

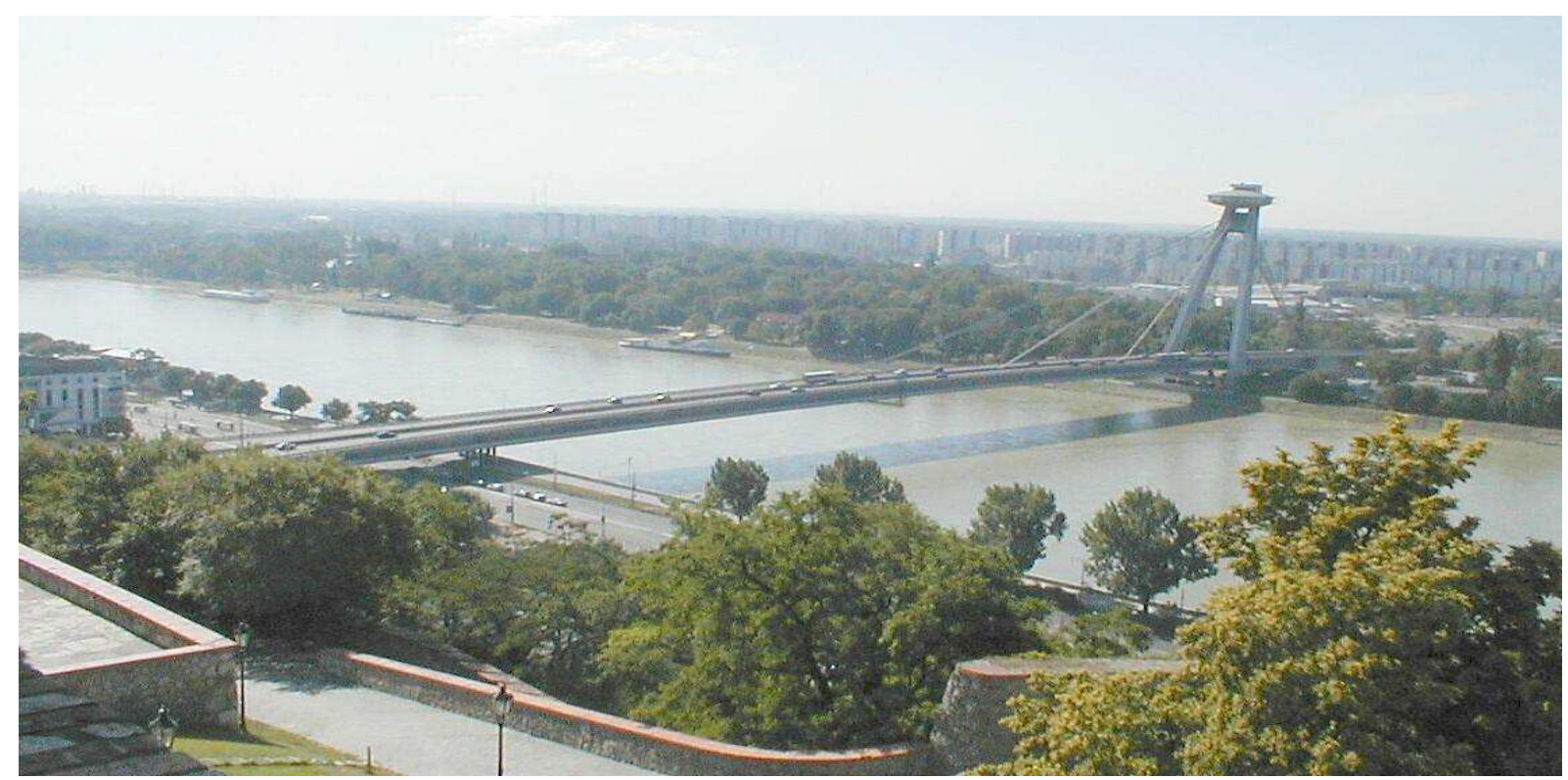

Fig. 2: The Bridge of Slovak National Uprising in Bratislava. 


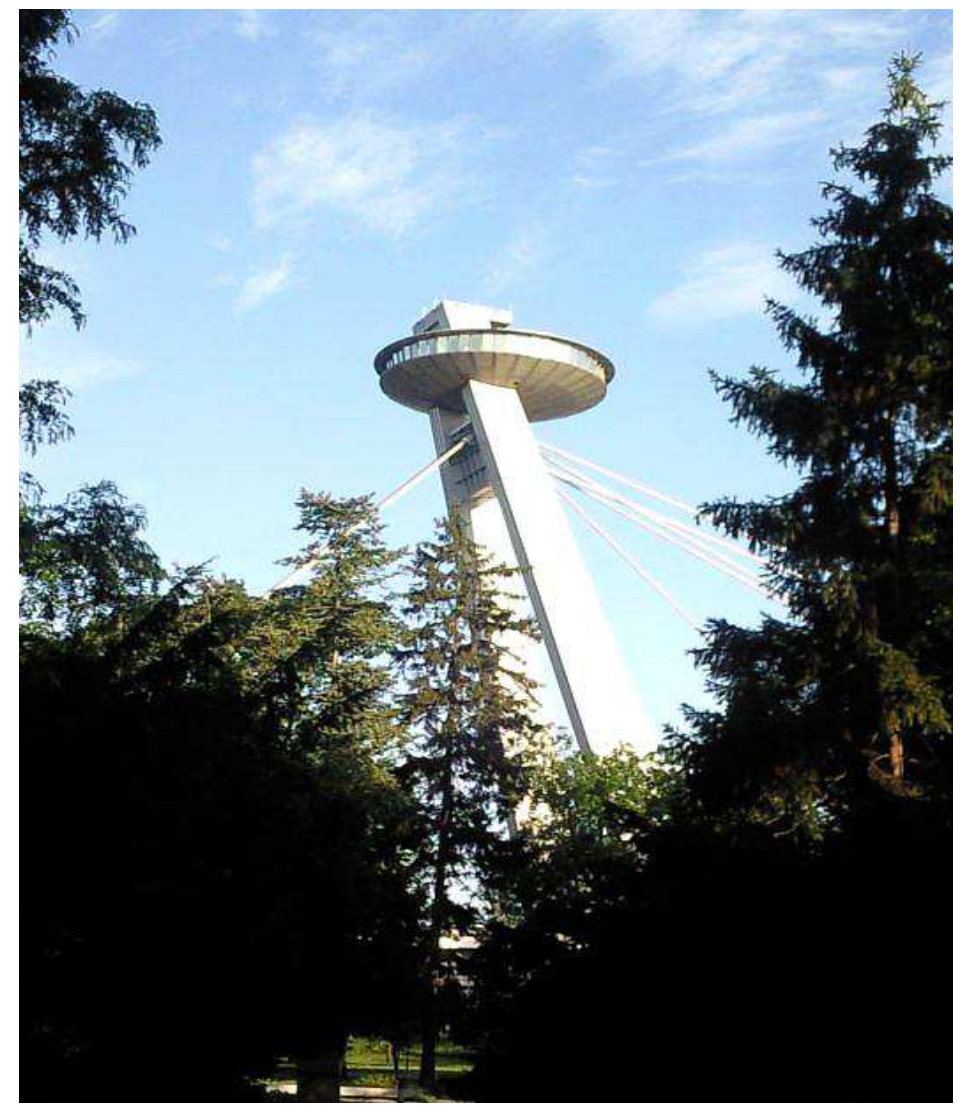

Fig. 3: Skew pylon of the bridge.

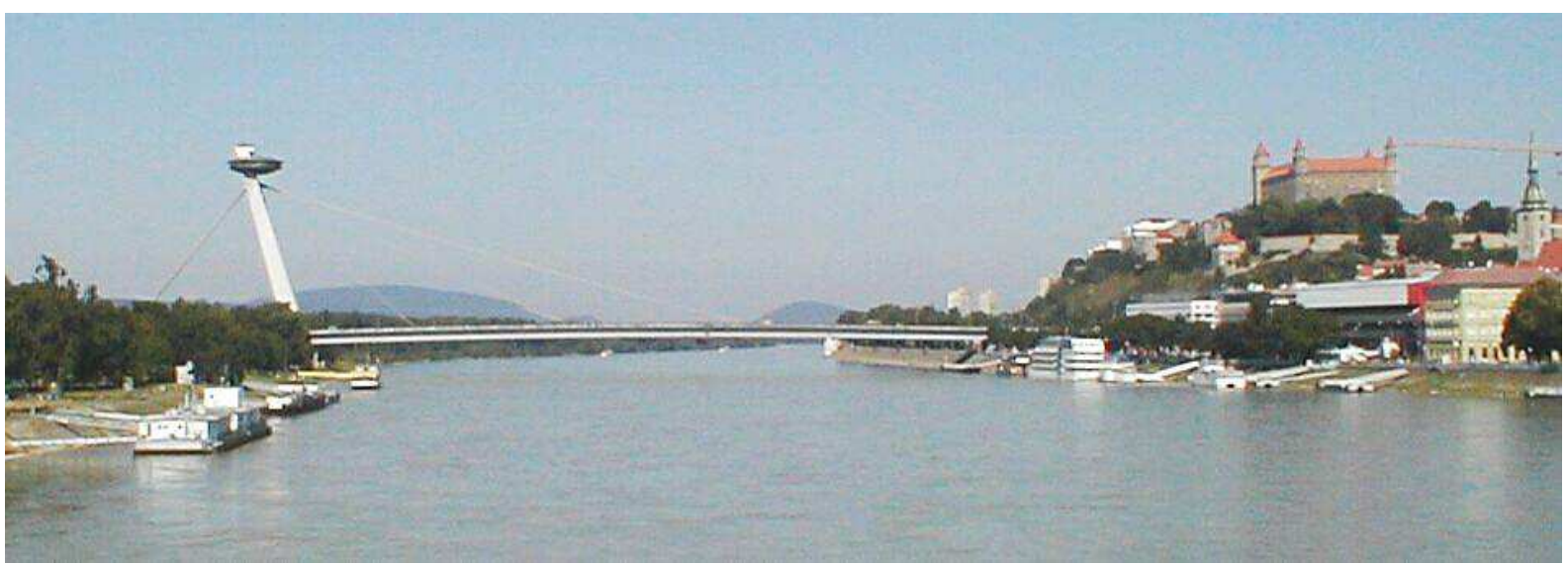

Fig. 4: The Bridge, Castle and Cathedral of St. Martin - silhouette.

Original engineering structures which he designed have led him to the development of new theories and calculation approaches in the scope of structural mechanics. His scientific works in the branch of thin-walled and shell structures as well as in the stability of steel constructions found high acknowledgment in scientific circles worldwide.

Together with professor Aurel Stodola, they are placed amongst significant Slovak engineers and scientists of the twentieth century. 